\title{
The works of Prince Qusun the Royal Waterer of Nazareth Architectural and Artistic City of Cairo
}

\author{
Gamal Abdel Rahim Ibrahim* \\ Faculty of Archeology, Cairo University, Egypt \\ *Corresponding author: Gamal Abdel Rahim Ibrahim, Professor, Faculty of Archeology, Cairo University, Egypt
}

\section{Editorial}

Prince Qusun, one of the most important Mamluks of Sultan al-Nasir Muhammad ibn Qalawun, had come to Egypt as part of a delegation from Barakad in Bukhara «the land of the Mongol Khan between India, China and Russia» accompanied by Khond Khond, the sister of Uzbeq Khan, who was married to al-Nasir Muhammad ibn Qalawun in 1320 AD. With him goods from his country worth 500 dirhams and went around the markets of Cairo to sell his goods, has been seen by King Sultan Nasser asked him Vdlh one of the custody of the Royal Stable, and admired the Sultan Nasser bought it was beautiful, and the Sultan loved him and annexed to the Mamluks and over the days made him a leader of a hundred The soldiers reached the highest rank in the Royal Palace was At the age of eighteen years, he brought his brothers and relatives, from the land of Bukhari, then the Sultan's wife, his daughter, and married his sister, and with the expiry of the Nasser, made him guardian of his children, in the year 1327.

When King Nasser felt that in the latter tendency, he asked Qusun to be the guardian of the throne and supervisor of his son, who chose him to the king after him, and Sultan Al-Nasser died in 741 Hijra, reassured that Qusun will return him beautiful, but Prince Qusun had a different opinion on Mansour Saif al-Din After three months after the death of his father, Abu Bakr sent him to prison and brought his younger brother and called him a successor to Mansour Saifuddin was named Ashraf Alaeddin Kajk, and the Egyptians His Highness Alaeddin small, and Qusun began to rule the country with all force and oppression, and the Mamluk princes revolted and arrested him in 1342 AD The rule of Sultan Ahmed bin Nasser conspired by senior princes envy and capture Les prison where he died in Alexandria.

It has the remaining architecture in Cairo, the mosque, the agency, the palace, the dome and the minaret.

\section{Collector}

The Qusun Mosque (known as Qaysun) is located on Muhammad Ali Street near the new Helmiyya area, specifically at the court of the court near Mughrabilin.It was built by the great Emir Saif alDin Qusun al-Saqi al-Nasiri in 730 AH-1330 AD, and was opened for prayer by Sultan al-Nasir Muhammad ibn Qalawun.

It was next to the mosque lane Almsamda of its western part is a large house known as "Prince Agus Namila" and then known as "Prince Jamal al-Din fighting seven Mosul" Prince Qusun took and demolished and took over the construction of this mosque on 21 Ramadan $730 \mathrm{AH}$.

The mosque was renovated, and its courtyard was rebuilt in 1893 during the reign of Khedive Abbas Hilmi II, and the present courtyard is covered with a wooden dome. Ali Mubarak said in the plans that a large part of Qusun Mosque was taken at the opening of Mohammed Ali Street, including the waterwheel and the minaret. Ali Mubarak laid down the plan to renovate the mosque and rebuild what was destroyed when he was minister of endowments, and the renovation was not completed until 1893.

The remains of the minaret disappeared with the expansion of Muhammad Ali Street in 1873, where the Ministry of Awqaf reconstructed its building in 1893 under the supervision of Ali Pasha Mubarak, as well as the remains of the mosque artifacts that used to illuminate the mosque, the Islamic Museum retains a brass openwork, composed of polygonal shape It has 12 ribs and four layers of rows of candles. The remains of the original mosque Qusun only the northern door and many stucco windows, decorations and writings that record the date of construction of the mosque and the name of the originator, and on the left shoulder the door sundial on the name of its maker Ahmed Hariri and the date of manufacture (1383). 
On the northern door overlooking the Saroujia Street, which is built with stone and followed by colored marble, it reads:

"Order to establish this blessed mosque with the generosity of the Almighty slave to God Almighty Qusun of the Royal Nazareth Waterer in the days of Mawlana Sultan, King Nasser, dearest supporters in the year thirty and seven hundred"

This phrase was written on the door.

\section{The palace}

This palace is located near Salah al-Din Square, in Manakh Waqf Street, off Sultan Hassan Street in the Caliph district, constructed by Prince Saif al-Din Qusun in 1238 AD and renovated by Prince Yashbak bin Mahdi in 1475 during the days of Sultan alAshraf Qaytbay in the Mamluk era. The name of Sultan al-Nasir Muhammad ibn Qala'un and the name of the prince is intertwined at the entrance to the main door, and most of the remaining parts of his era are now intertwined. A member of the government of Sultan al-Ashraf Qaytbay, he was known to Nation Bhouc «Brdq» distortion for «Ocyprda».

It is known historically that the basis of the Palace of Qusun «Stable», and has two doors, a door from the street next to the cow, and the other door towards the door of the chain that leads to the Royal Stable and the castle of the mountain, was established by Prince Alamuddin Singer Jamakdar, and took him from Prince Seif Eddin Qusun and spent him Its price is from the house of money.

Historical sources mention that the palace was characterized by exquisite decorations, roofs decorated with gold water, marble fountain in the middle, and marble floor, which testifies to the beauty of Islamic architecture during the Mamluk period, and the door of the main palace, and was located in the northwest facade crowned by a city contract decorated with colored marble, It also has decorations carved on the stone, and includes a founding painting in the name of Sultan al-Nasir Muhammad ibn Qalawun, as well as the name of the makers of the palace, Mohammed bin Ahmed, and Ahmed Zaalash Shami. The basement of the palace is used as stables and warehouses, while a magnificent reception hall is topped by these stores.

\section{Agency}

Located in Bab El-Nasr Street in aesthetic. Established by Prince Seif Eddine Qusoun Al-Saki Al-Nasiri in 1341, leaving only the entrance, which is a stone with a closed door opening with a huge wooden shutter free of decorations. This blessed Khan established the high Ashrafiye residence of Qusun, the royal sage of Nazareth, Adam Allah Azza.

The entrance is made of granite and is moved from an Egyptian temple containing Egyptian inscriptions to be the largest movable granite piece containing Egyptian inscriptions in Islamic architecture in Cairo.

\section{The dome and minaret}

Al-Maqrizi mentioned it in his plans. It was destroyed, leaving only the dome and the large or central lighthouse west of the shrine of Sheikh Jalal al-Din al-Suyuti outside the door of the Qarafa in the caliph. The dome is one of the most important domes of the Mamluk style domes. Or polygonal cupolas.

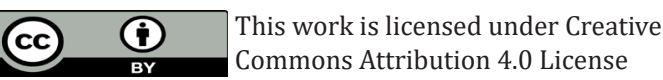

To Submit Your Article Click Here: Submit Article

DOI: $10.32474 / J A A S .2019 .01 .000105$

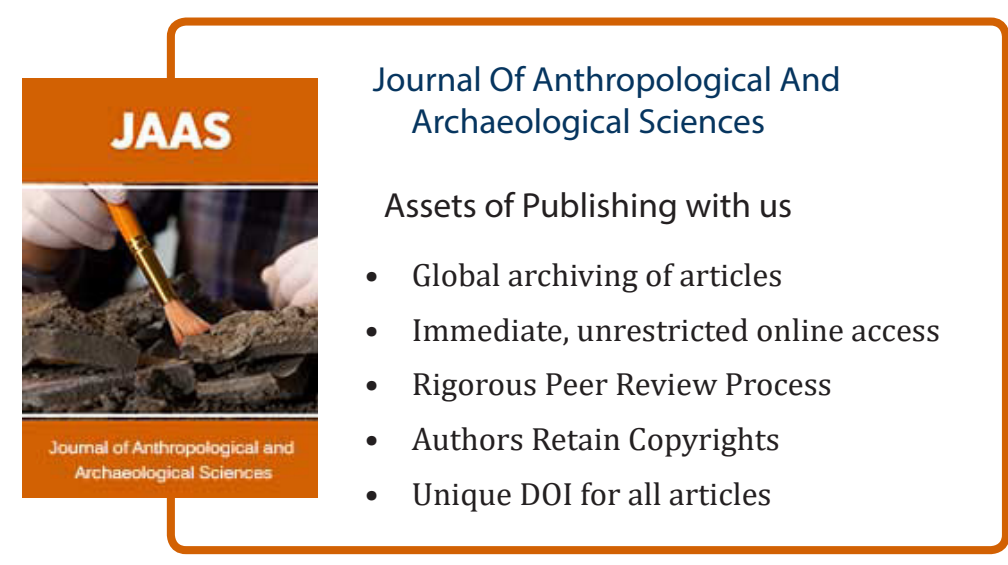

